International Research Journal of Engineering, IT \& Scientific Research (IRJEIS)

Available online at http://ijcu.us/online/journal/index.php/irjeis

Vol. 3 Issue 3, May 2017, pages: 38 48

ISSN: 2454-2261 Impact Factor: 5.211 | Thomson Reuters: K-4290-2016

: http://dx.doi.org/10.21744/irjeis.v3i3.454

\title{
Utilization of Biochar, Compost and Phonska in Improving Corn Results on Dry Land
}

Article history:

Received: 10 November 2016 Revised: 5 March 2017

Approved: 1 April 2017

Published: 8 May 2017

\section{Keywords:}

Biochar;

Dryland;

Phonska;

Compost;

Corn Results;

\author{
Abstract
}

This study aims to obtain the best dose or optimum dose of biochar, compost, and phonska in improving the yield of corn in the dry land. This experiment used a randomized block design (RBD) 3 replication with a nested experiment, where the dose factor was nested in each type of fertilizer. The treatment factor consisted of 3 types of fertilizer $(\mathrm{J})$, namely: biochar (B), compost (K), and phonska (P) with 3 fertilizer doses (D) and a control as a comparison. The results showed that the dosage of biochar $10 \mathrm{t}$ $\mathrm{ha}^{-1}$ could increase the highest total oven dry weight of $509.31 \mathrm{~g}$, which increased by $23.95 \%$ when compared with without biochar of $410.90 \mathrm{~g}$. Composting doses of $20 \mathrm{tha}^{-1}$ can yield the highest total dry weight of the oven of $525.05 \mathrm{~g}$, an increase of $27.78 \%$ when compared with no treatment of $410.90 \mathrm{~g}$. Phonska dosage of $300 \mathrm{~kg} \mathrm{ha}^{-1}$ can give the highest yield of the dry weight of the highest total plant oven of 563,91 g, increasing by $37,24 \%$ when compared with without treatment equal to $410,90 \mathrm{~g}$. The results of this study obtained the optimum dose of biochar $10.52 \mathrm{t} \mathrm{ha}^{-1}$, compost 20,22 $\mathrm{t} \mathrm{ha}^{-1}$, and phonska $313,37 \mathrm{~kg} \mathrm{ha}^{-1}$ that can be used to improve a yield of the corn plant in the dry land.

2454-2261@ Copyright 2017 The Author. Published by International Journal of College and University. This is an open access article under the CC-BY-SA license (https://creativecommons.org/licenses/by/4.0/) All rights reserved.

\section{Author correspondence:}

Yohanes Parlindungan Situmeang,

Faculty of Agriculture, Warmadewa University, Denpasar-Bali.

Email address: ypsitumeang63@gmail.com

\section{Introduction}

Corn of Bisi2 is included in a single cross hybrid class. The stems of corn plants are tall and erect, with a plant height of about $232 \mathrm{~cm}$. The leaves of corn plants are bright green, long, wide and drooping. The position of the corn cob in the middle of the stem height. Medium-sized corn cubes with cylindrical and uniform shapes. Corn weights cover the cob well so as to avoid the entry of rainwater into the cob. The number of rows in a cob hybrid of bisi2 corn ranges from 12-14 lines. Semi-seed type and orangeyellow seed color. Based on the decryption of hybrid maize bisi2, that the potential yield could reach $13 \mathrm{t}$ $\mathrm{ha}^{-1}$ dry pipeline, with an average yield of $8.9 \mathrm{t} \mathrm{ha}^{-1}$ dry pipeline. The weight of 1,000 grains of hybrid corn seeds of $15 \%$ moisture content is about $265 \mathrm{~g}$. Entering the age of about 56 days, $50 \%$ hair cob hybrid bisi 2 corn out and harvest done when corn is ripe physiological age of about 103 days.

The main problems in the cultivation of maize in the dry land that causes low productivity, among others the use of low yield potential varieties, low plant population, low fertilizer dosage, nutrient availability and low organic matter content in soil, and water stress due to drought. According to [1], the

${ }^{a}$ Faculty of Agriculture, Warmadewa University, Denpasar, Bali 
main constraints are often found in dry land is low productivity level, characterized by soil with advanced weathering, thick red solum, high clay content, acid soil reactions, cation exchange capacity and low base saturation, poor nutrients especially phosphorus, low organic matter content, high iron and aluminum content exceeding the limit of plant tolerance and erosion sensitive. The low quality of dry land can be rehabilitated with the use of balanced fertilizers, namely the availability of organic materials and inorganic materials in the soil. Organic materials can be biochar soil enhancers and compost, while inorganic materials are NPK phonska fertilizers.

The use of biochar in dryland can increase the total C-total, $\mathrm{pH}$, and CEC content of the soil, increasing the soil's ability to water and nutrient. Biochar can be produced by pyrolysis through incomplete combustion of agricultural waste biomass especially bamboo waste. This pyrolysis-biochar can be used as a soil enhancer to bind carbon, producing excellent fibers and highly porous charcoal which helps the soil to retain nutrients and water [2]. Biochar is added to the soil to improve soil function and reduce emissions from biomass that naturally break down into greenhouse gasses. Biochar in the soil is recalcitrant which is weather resistant or difficult to decompose and can improve soil physical properties and low soil quality in the dry land [3]. Biochar affects soil quality in various ways, including increasing porosity, volume weight and water availability, increasing $\mathrm{pH}, \mathrm{C}$-organic, $\mathrm{P}, \mathrm{K}$, and $\mathrm{CEC}$, reducing $\mathrm{N}$ leaching and increasing microbial population activity [4], [5].

The use of compost is very helpful in improving the degraded soil because organic fertilizer can bind nutrients that easily disappear and help in the provision of soil nutrients so that the efficiency of fertilization becomes higher. Provision of compost fertilizer, in addition, can increase the availability of nutrients, can also improve soil physical properties such as aggregate stability, volume weight, total pore space, plasticity, permeability, and holding a power of water. The nutrients derived from compost are required by soil microbes to be transformed from complex organic forms that the plant can not utilize into simple organic and inorganic compounds that can be absorbed by plants [6]. Organic matter is decomposed by microorganisms into elements that are returned to the soil such as $\mathrm{N}, \mathrm{P}, \mathrm{K}, \mathrm{Ca}, \mathrm{Mg}$, etc. as nutrients that can be reused by plants so that the nutrient cycle runs properly.

The use of phonska containing $15 \% \mathrm{~N}, 15 \% \mathrm{P}, 15 \% \mathrm{~K}$, and $10 \% \mathrm{~S}$ can increase production and quality of harvest, increase plant resistance to pest and disease diseases, make plants greener, spur root growth, spur interest formation, and enlarge the size of fruits, tubers, and seeds [7]. Nutrient concentration in phonska compound fertilizer shows that this fertilizer has balanced nutrient availability. Compound fertilizers can be used at the beginning of planting to accelerate the development of seedlings and as follow-up fertilizer when the plant enters the generative phase when the plant begins to bloom or bear fruit [8].

Research on the use of biochar, compost, and phonska, especially to get the right dose for soil quality improvement and corn production is still very limited. Results of the study [3], indicated that the introduction of biochar soil enhancers with doses of 5.0-7.5 $\mathrm{t} \mathrm{ha}^{-1}$ was able to improve the physical, chemical, and biological properties of the soil, by increasing the percentage of available pore water, Pavailable, K-total, CEC, and respiration of soil microorganisms. Furthermore, [5], reported that biochar utilization with a dose of $12 \mathrm{tha}^{-1}$ had a significant effect on soil quality improvement, ie volume weight and K-available, while also significantly affecting corn plant height. The results of the study [9], reported that biochar dose of $10 \mathrm{t} \mathrm{ha}^{-1}$ had the significant effect on plant height, the total wet weight of the plant, and total oven dry weight of corn plant. Giving biochar of rice husks $9,28 \mathrm{t} \mathrm{ha}^{-1}$ on soil contaminated garment waste can decrease the weight of contents, increasing porosity, CEC, P-available, K-available, and decreasing concentration of heavy metals $\mathrm{Cu}, \mathrm{Pb}, \mathrm{Cd}$, and $\mathrm{Cr}$ in $\mathrm{In}$ the soil, as well as increasing the dry weight of oven stover and corn crop yields [10]. Biochar dosing of $10 \mathrm{t} \mathrm{ha}^{-1}$ and phonska $300 \mathrm{~kg} \mathrm{ha}^{-1}$ fertilizer and $20 \mathrm{t} \mathrm{ha}^{-1}$ compost can increase the growth and yield of maize crops [11]. Furthermore, [12] doses of bamboo biochar 5-10 $\mathrm{tha}^{-1}$ gave the best fresh weight of the cob and the compost dosage of 7.5$15.0 \mathrm{t} \mathrm{ha}^{-1}$ gave the best results in plant height, fresh weight of cob, and fresh weight Corn stover.

Research on the benefits of biochar, compost, and phonska is still needed to improve corn yield in the dry land. The improvement of corn production on dry land is very strategic in the future through the improvement of agricultural cultivation, especially the utilization of soil biochar, compost, and phonska fertilizer.

This study aims to obtain the best dose or optimum dose of biochar, compost, and phonska in improving the yield of corn crops in the dry land. The hypothesis proposed in this study is that the dosage of biochar $10 \mathrm{t} \mathrm{ha}^{-1}$, compost $20 \mathrm{t} \mathrm{ha}^{-1}$, and phonska $300 \mathrm{~kg} \mathrm{ha}^{-1}$ can increase the yield of corn.

\section{Research Methods}

\subsection{Research Design}

This experiment used a randomized block design (RBD) 3 replication with a nesting experimental pattern, where the dose factor was nested in each type of fertilizer. The treatment factor consisted of 3 
types of fertilizer (J), namely: biochar (B), compost (K), and phonska (P) with 3 fertilizer dosage levels (D) and a control as a comparison so that 10 treatments were obtained with a total of 30 experimental units. The composition of the experimental treatment was as follows: (1) control (D0), (2) Biochar Dose 5 $\mathrm{t} \mathrm{ha}^{-1}\left(\mathrm{BD}_{1}\right)$, (3) Biochar Dose $10 \mathrm{t} \mathrm{ha}^{-1}\left(\mathrm{BD}_{2}\right)$, (4) Biochar Dose $15 \mathrm{t} \mathrm{ha}^{-1}\left(\mathrm{BD}_{3}\right)$, (5) Compost Dose $10 \mathrm{t}$ $\mathrm{ha}^{-1}\left(\mathrm{KD}_{1}\right)$, (6) Compost Dose $20 \mathrm{t} \mathrm{ha}^{-1}\left(\mathrm{KD}_{2}\right)$, (7) Compost Dose $30 \mathrm{t} \mathrm{ha}^{-1}\left(\mathrm{KD}_{3}\right)$, (8) Phonska Dose 150 $\mathrm{kg} \mathrm{ha}^{-1}\left(\mathrm{PD}_{1}\right),(9)$ Phonska Dose $300 \mathrm{~kg} \mathrm{ha}^{-1}\left(\mathrm{PD}_{2}\right)$, and (10) Phonska Dose $450 \mathrm{~kg} \mathrm{ha}^{-1}\left(\mathrm{PD}_{3}\right)$.

\subsection{Location and Time of The Study}

The experiment was conducted at greenhouse location Faculty of Agriculture, Udayana University. Soil media for pots are taken from dry land in Sulahan Village, District of Susut, Bangli Regency. Soil properties, biochar, and compost fertilizer were analyzed at Soil Science Laboratory of Udayana University Faculty of Agriculture and Laboratory of Agriculture Faculty of Warmadewa University, Denpasar. Analysis of SEM (Scanning Electron Microscope) to determine the morphology of biochar is done at the Metallurgical Laboratory of Mechanical Engineering Faculty of Engineering Udayana University. The study was conducted from June to December 2015.

\subsection{Materials and Tools}

The materials used are biochar from bamboo waste, compost, and soil media, hybrid corn seeds bisi2, fertilizer NPK phonska (15-15-15), urea fertilizer, polybag (pot), plastic bags, and insecticides. The equipment used in this study is the hoe, rake, sieve the soil (size $2 \mathrm{~mm}$ ), sickles, machetes, knives, scales, sprayer, metered, and stationery.

\subsection{Preparation of Soil Media, Biochar, and Compost}

Soil media, bamboo biochar, and compost were taken from the research site in Sulahan Village, District of Susut, Bangli Regency. The soil media picking is done by first clearing a surface of the soil from the grass and plants growing on it, the soil is hoisted as deep as $20 \mathrm{~cm}$ and stirred evenly, then the soil sieved with a $2 \mathrm{~mm}$ sieve, the result of this filter is directly inserted into 40 pots. The soil used as a planting medium for each pot is $20 \mathrm{~kg}$ (absolute dry soil weight) obtained after the determination of moisture content with a number of wet-dried soils at $105^{\circ} \mathrm{C}$.

Bamboo charcoal is obtained from Sulahan Village, District of Susut, Bangli District. Bamboo charcoal is then processed and produced into biochar powder form in the laboratory of the Faculty of Agriculture, University of Warmadewa, while cow manure compost is obtained from the cage Simantri 380 in the village of Sulahan, district of Susut, Bangli Regency.

Biochar and compost treatment was given once a week before planting by mixing biochar in each pot according to treatment dosage, while phonska fertilizer treatment was given when planting with the appropriate dose of treatment. The need for fertilizer per pot in each treatment can be calculated by the formula:

$$
\text { Dosage of fertilizer per pot }(\mathrm{g})=\frac{\text { Soil weight in pot }(\mathrm{kg})}{\text { weight of soil } 1 \mathrm{ha}(\mathrm{kg})} \times \text { dose of fertilizer }
$$

\subsection{Preparation of Planting, Planting, and Harvesting}

Planting of corn seeds is done after all pots weighing $20 \mathrm{~kg}$ arranged on the table experiment with spacing between pots $80 \mathrm{~cm} \times 40 \mathrm{~cm}$. Planting is done by inserting two corn seed into the drill hole as deep as $3 \mathrm{~cm}$, after which the hole is closed again with soil. After all the corn plants in each pot grow evenly then thinning with one plant per pot.

Maintenance of plants during the study, such as watering plants in the pot is done every day in the afternoon. Pest control is done by insecticide Matador 25 EC and Confidor 5WP and to cope with ants and flies seeds used Furadan 3G. Harvest on corn crop is done at age 103 days after planting, that is when corn seed is ripe physiologically.

\subsection{Research Variable}

The variables observed in this study were a fresh weight of cobs without weight, fresh weight of seed, dry weight of $14 \%$ moisture content, dry weight of stover, and total dry weight of the plant.

\subsection{Data Analysis}

Variant analysis (ANOVA) was used to determine the effect of dosage treatment from biochar, compost, and phonska on observed variables. The smallest real difference test (LSD) at the 5\% level was used to determine the difference in mean values for each observed variable. Regression analysis was used 
to determine the optimum dose of the observed treatment. Data processing is done using Microsoft excel and Minitab14.

\section{Results and Analysis}

\subsection{Potential and Characteristics of Biochar and Compost}

The potential of bamboo waste as raw material for biochar production in Bangli Regency is very large. The total area of the bamboo plantation reaches 10,500 ha and has the potential to produce large amounts of bamboo waste raw material to a total of 3,106 tons per day, and about 200 ha of community managed bamboo land can produce about 30 tons of bamboo waste per day [13]. Bamboo waste has the opportunity to be utilized as raw material for making biochar. The abundant bamboo waste can be processed into biochar that can be utilized as a soil enhancer to improve soil quality and maize production.

Biochar bamboo in the study is produced by pyrolysis. Pyrolysis is the process of thermal decomposition of organic substrates or biomass in the absence of oxidizing agents or the limited supply of oxygen during the biomass burning process. Making bamboo biochar is done by slow pyrolysis process by burning bamboo waste in the container of the hole in the soil with temperature $<4000 \mathrm{C}$ to become bamboo charcoal, and to get bamboo charcoal biochar powder is then smoothed and filtered with 20 mesh sieve. The resulting biochar has a rendemen ranging from $40-50 \%$.

The results of the Scanning Electron Microscope (SEM) test at 500x, 1000x, and 2000x enlargement of bamboo biochar were obtained by biochar morphology with micropore structure scattered on the surface of biochar (Fig. 1).

The physical characteristics of the biochar surfaces of the 2000x enlarged SEM (Fig. 1) clearly show the biochar morphology with large surface area and micropore structure scattered on the biochar surface. Very porous biochar pores lead to improved aeration and drainage systems and increased soil ability to absorption and water in the soil. Biochar has higher stability characteristics against decomposition and is able to absorption and water well than other organic materials, due to larger surface area and negative surface [14], [15]. Biochar bamboo has a highly microporous structure, with adsorption efficiency about ten times higher than traditional wood biochar [16].

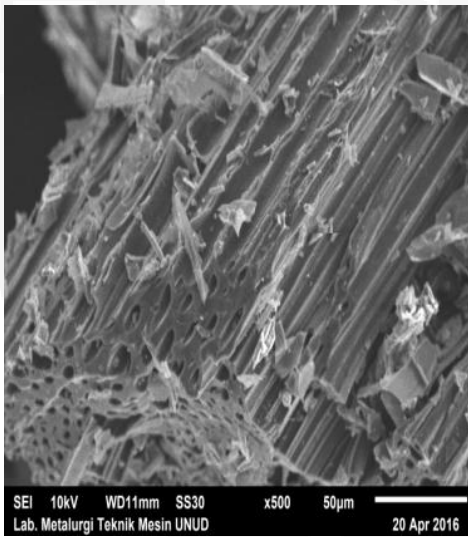

$500 x$

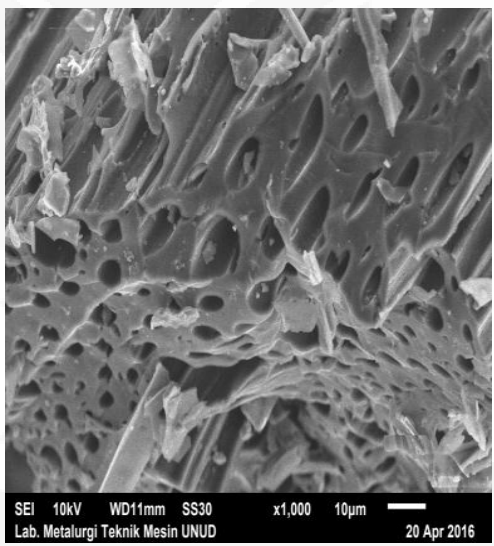

1000x

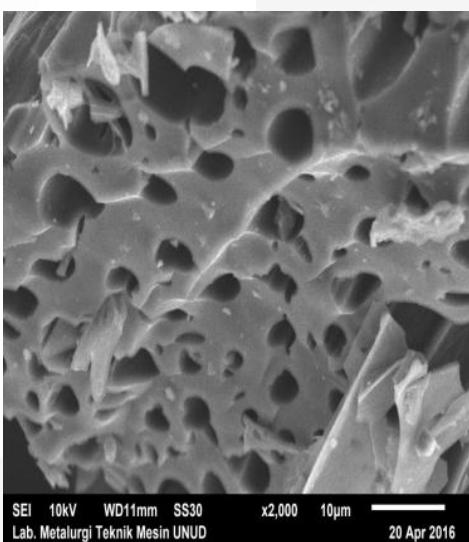

2000x

Figure 1. SEM Test Results of Biochar Bamboo at 500x, 1000x, and 2000x Magnification

The potential of organic material of cow dung as a raw material for composting in Bali is very large. The program of the integrated agricultural system (Simantri) of Bali regional government spread all over Regency / Municipality in Bali is the supplier of sustainable cow dung raw material for compost production. Farmer group that joined in the program of Simantri until an end of the year 2015 amounted 550. In this research compost used is obtained from Simantri 380, Gapoktan Mina Karya Winangun, Village Sulahan District of Susut Bangli Regency, which is about $200 \mathrm{~m}$ from the research location. The results of characteristic analysis of biochar and compost properties are presented in Table 1. 
Table 1

Results of Analysis Characteristics of Biochar and Compost (\#)

\begin{tabular}{|c|c|c|c|}
\hline No & Type Analysis & Biochar Bamboo & Compost \\
\hline 1. & $\mathrm{pH} \mathrm{H} \mathrm{H}_{2} \mathrm{O}$ & 7.48 & 7.35 \\
\hline 2. & $\mathrm{EC}(\mathrm{mmhos} / \mathrm{cm})$ & 0.77 & 10.92 \\
\hline 3. & C-organic $(\%)$ & 3.08 & 15.51 \\
\hline 4. & N-total $(\%)$ & 0.06 & 0.82 \\
\hline 5. & $\mathrm{C} / \mathrm{N}$ & 51.33 & 18.91 \\
\hline 6. & Organic matter (\%) & 5.31 & 26.75 \\
\hline 7. & P-available (ppm) & 451.78 & 650.14 \\
\hline 8. & K-available (ppm) & 36.07 & 23.26 \\
\hline 9. & $\mathrm{Ca}(\mathrm{mg} / \mathrm{kg})$ & 32.20 & 9.28 \\
\hline 10. & $\mathrm{mg}(\mathrm{mg} / \mathrm{kg})$ & 15.88 & 15.16 \\
\hline 11. & $\mathrm{Na}(\mathrm{mg} / \mathrm{kg})$ & 14.62 & 15.26 \\
\hline 12. & KU water content $(\%)$ & 5.48 & 22.47 \\
\hline
\end{tabular}

Description: \# Laboratory of Soil Science Faculty of Agriculture, Udayana University

Table 1 shows that biochar has a $\mathrm{pH}, \mathrm{C} / \mathrm{N}, \mathrm{K}, \mathrm{Ca}$, and $\mathrm{Mg}$ relatively higher than in compost, otherwise compost has EC, $\mathrm{C}$-organic, $\mathrm{N}$-total, $\mathrm{P}$-available, $\mathrm{Na}$, and relative water content higher than biochar. Both types of organic materials, biochar and compost have different characteristics, but these two materials have the same purpose and complement each other in improving soil properties in dry land, ie increasing the ability of soil in storing water and nutrients, increasing porosity and decreasing the weight of volume Soil, increase C-organic, N, P, CEC, BS, and total microbes in the soil.

\subsection{Characteristics of Dryland}

Sulahan Village, Susut district, Bangli Regency was chosen as the location for the sampling of research soil because it has a large dry land potential to be developed for food crops, especially maize. The location of sampling of soil research with soil type of regosol humus is at coordinate $08^{0} 23^{\prime} 59,05$ "SL and $115^{\circ} 20^{\prime} 54,69^{\prime \prime}$ EL with a height of place $762 \mathrm{~m}$ above sea level. Characteristics of soil physical and chemical properties of the study are presented in Table 2.

Table 2

Characteristics of Physical and Chemical Properties of The Soil Before Experiment (\#)

\begin{tabular}{|c|c|c|c|}
\hline Soil physical properties & Status & Soil chemical properties & Status \\
\hline 1. Water content DA (\%) & $6,19(\mathrm{~L})$ & 1. $\mathrm{pH} \mathrm{H}_{2} \mathrm{O}$ & $6.82(\mathrm{~N})$ \\
\hline 2. Water content $\mathrm{CF}(\%)$ & $26.65(\mathrm{H})$ & 2. $\mathrm{EC}\left(\mathrm{mmhos} \mathrm{cm}^{-1}\right)$ & $0.43(\mathrm{VL})$ \\
\hline 3. Heavy volume $\left(\mathrm{g} \mathrm{cm}^{-3}\right)$ & $0.97(\mathrm{VL})$ & 3. C-organic $(\%)$ & $2.69(\mathrm{M})$ \\
\hline 4. Porosity $(\%)$ & $63.54(\mathrm{VH})$ & 4. N-total $(\%)$ & $0.19(\mathrm{~L})$ \\
\hline 5. Texture & SL & 5. $\mathrm{C} / \mathrm{N}$ & $14.16(\mathrm{M})$ \\
\hline a. Sand (\%) & 60.30 & 6. Organic matter $(\%)$ & $4.64(\mathrm{M})$ \\
\hline b. Dust (\%) & 30.10 & 7. P-available (ppm) & $31.08(\mathrm{H})$ \\
\hline \multirow[t]{6}{*}{ c. Clay (\%) } & 9.60 & 8. K-available (ppm) & 31.75 (VL) \\
\hline & & 9. $\mathrm{Ca}(\mathrm{mgkg}-1)$ & $1.64(\mathrm{VL})$ \\
\hline & & $10 \mathrm{Mg}(\mathrm{mg} \mathrm{kg}-1)$ & $12.50(\mathrm{M})$ \\
\hline & & 11. $\mathrm{Na}(\mathrm{mg} \mathrm{kg}-1)$ & $9.96(\mathrm{H})$ \\
\hline & & 12. CEC (me / 100g) & $16.14(\mathrm{M})$ \\
\hline & & 13. BS $(\%)$ & $55.89(\mathrm{H})$ \\
\hline
\end{tabular}

Specification: DA (Dry Air) CF (Capacity Field), SL (Sandy Loam), EC (Electrical Conductivity), CEC (Cation Exchange Capacity), BS (base saturation), N (Neutral), VL (Very Low), L (Low), M (Medium), H (High), VH (Very High). \# Laboratory of Soil Science, Faculty of Agriculture, Udayana University (2015).

The result of soil analysis in Table 2 shows that the land where the research is characterized by soil physical properties such as sandy loam texture class, a moisture content of high capacity, very low soil volume, and very high porosity of the soil. Characteristics of soil chemical properties include very low EC, C-organic and medium organic material, low N-total, C / $\mathrm{N}$ ratio of 14.64, while P-available is high, while $\mathrm{K}$-available is very low, and CEC is medium. The characteristics of the research area with very low 
$\mathrm{EC}$, $\mathrm{K}$-available, and $\mathrm{Ca}$, and $\mathrm{C}$-organic, $\mathrm{Mg}$, and $\mathrm{CEC}$ are moderately classified, soil ability can be improved so that the plants can grow well through the provision of organic materials derived from biochar and compost.

\subsection{The Fresh Weight of The Cob Without Husk}

The highest weight of cobs without the highest weight was obtained at a dose of biochar $10 \mathrm{tha}^{-1}$ $\left(\mathrm{BD}_{2}\right)$ weighing $240.00 \mathrm{~g}$ which was not significantly different with $5 \mathrm{t} \mathrm{ha}^{-1}\left(\mathrm{BD}_{1}\right)$ and $15 \mathrm{t} \mathrm{ha}^{-1}\left(\mathrm{BD}_{3}\right)$ respectively $226,33 \mathrm{~g}$ and $222.80 \mathrm{~g}$, but significantly different with no biochar $\left(\mathrm{D}_{0}\right) 179.63 \mathrm{~g}$. Treatment of compost doses of $30 \mathrm{t} \mathrm{ha}^{-1}\left(\mathrm{KD}_{3}\right)$ gave a fresh weight of cobs without the highest weight of $232.43 \mathrm{~g}$ which was significantly different from compost $\left(\mathrm{D}_{0}\right)$, but not significantly different with $20 \mathrm{t} \mathrm{ha}^{-1}\left(\mathrm{KD}_{2}\right)$ and $10 \mathrm{t} \mathrm{ha}^{-1}\left(\mathrm{KD}_{1}\right)$ respectively $230.10 \mathrm{~g}$ and $220.03 \mathrm{~g}$. Phonska dose treatment $300 \mathrm{~kg} \mathrm{ha}^{-1}\left(\mathrm{PD}_{2}\right) \mathrm{gave}$ fresh weight of cob without the highest weight $284,80 \mathrm{~g}$, which was not significantly different with phonska $450 \mathrm{~kg} \mathrm{ha}^{-1}\left(\mathrm{PD}_{3}\right)$ that was $266,33 \mathrm{~g}$, but significantly different with $150 \mathrm{~kg} \mathrm{ha}^{-1}\left(\mathrm{PD}_{1}\right)$ and without phonska $\left(\mathrm{PD}_{0}\right)$ respectively $233.10 \mathrm{~g}$ and $179.63 \mathrm{~g}$ (Table 3$)$. The results of the statistical analysis showed that the dosing interval of 5-15 $\mathrm{t} \mathrm{ha}^{-1}$ biochar, 10-30 $\mathrm{t} \mathrm{ha}^{-1}$ compost, and 300-450 kg ha-1 phonska gave the best value fresh weight of cob without husk, while without fertilizer gave the lowest value.

\subsection{Fresh Seed Weight}

The highest weight of fresh seed is obtained at the dose of biochar $10 \mathrm{t} \mathrm{ha}^{-1}\left(\mathrm{BD}_{2}\right)$ weighing $170.83 \mathrm{~g}$ and the lowest in the treatment without biochar $\left(D_{0}\right)$ is $142.03 \mathrm{~g}$. Treatment of compost doses of $30 \mathrm{t} \mathrm{ha}^{-1}$ $\left(\mathrm{KD}_{3}\right)$ tended to give the highest fresh weight of $177.00 \mathrm{~g}$ and the lowest in the composted treatment $\left(\mathrm{D}_{0}\right)$ of $142.03 \mathrm{~g}$. Phonska dose treatment of $450 \mathrm{~kg} \mathrm{ha}^{-1}\left(\mathrm{PD}_{3}\right)$ gave the highest fresh seed weight of $198.53 \mathrm{~g}$, which was significantly different from the treatment without phonska $\left(\mathrm{D}_{0}\right)$ of $142.03 \mathrm{~g}$, but not significantly different with phonska $300 \mathrm{~kg} \mathrm{ha}^{-1}\left(\mathrm{PD}_{2}\right)$ and $150 \mathrm{~kg} \mathrm{ha}^{-1}\left(\mathrm{PD}_{1}\right)$ respectively $189.10 \mathrm{~g}$ and $171.70 \mathrm{~g}$ (Table 3). These results indicate that the treatment dose of $0-15 \mathrm{t} \mathrm{ha}^{-1}$ biochar, $0-30 \mathrm{t} \mathrm{ha}^{-1}$ compost and 150-300 $\mathrm{kg} \mathrm{ha}^{-1}$ phonska gave the highest value of fresh seed weight, whereas without fertilizer gave the lowest value.

\subsection{Dry Weight of Seeds Moisture Content 14\% (g)}

The dry weight of the highest moisture content of $14 \%$ was obtained at the dose of biochar $10 \mathrm{tha}^{-1}$ $\left(\mathrm{BD}_{2}\right)$ weighing $158.99 \mathrm{~g}$ and the lowest in treatment without biochar $\left(\mathrm{D}_{0}\right)$ ie $130.85 \mathrm{~g}$. Treatment of compost doses of $30 \mathrm{t} \mathrm{ha}^{-1}\left(\mathrm{KD}_{3}\right)$ tended to give the highest dry weight of $154.96 \mathrm{~g}$ and the lowest in the composted treatment $\left(\mathrm{D}_{0}\right)$ of $130.85 \mathrm{~g}$. Phonska dose treatment of $450 \mathrm{~kg} \mathrm{ha}^{-1}\left(\mathrm{PD}_{3}\right)$ gave the highest dry weight of $168.53 \mathrm{~g}$, which was significantly different from the treatment without phonska $\left(\mathrm{D}_{0}\right)$ of 130.85 $\mathrm{g}$, but not significantly different with phonska $300 \mathrm{~kg} \mathrm{ha}^{-1}\left(\mathrm{PD}_{2}\right)$ and $150 \mathrm{~kg} \mathrm{ha}^{-1}\left(\mathrm{PD}_{1}\right)$ of $175.74 \mathrm{~g}$ and $154.57 \mathrm{~g}$ respectively (Table 3 ). Based on the above description it can be seen that the dosing interval of 0-15 $\mathrm{t} \mathrm{ha}^{-1}$ biochar, 0-30 $\mathrm{t} \mathrm{ha}^{-1}$ compost, and 150-450 kg ha-1 phonska gives the best value of the dry weight of $14 \%$ moisture content.

\subsection{Dry Weight of Stover}

The highest dry weight of the highest plant stalk was obtained at a dosage of $10 \mathrm{t} \mathrm{ha}^{-1}\left(\mathrm{BD}_{2}\right)$ of 343.58 $\mathrm{g}$ which was not significantly different from $5 \mathrm{t} \mathrm{ha}^{-1}\left(\mathrm{BD}_{1}\right)$ and without biochar $\left(\mathrm{D}_{0}\right)$ of $276.48 \mathrm{~g}$ and $251.10 \mathrm{~g}$ respectively, but significantly different with biochar $15 \mathrm{t} \mathrm{ha}^{-1}\left(\mathrm{BD}_{3}\right) 304,68 \mathrm{~g}$. Treatment of compost dose of $20 \mathrm{t} \mathrm{ha}^{-1}\left(\mathrm{KD}_{2}\right)$ gave the highest dry weight of $342.52 \mathrm{~g}$ of plant stool which was significantly different from compost $\left(\mathrm{D}_{0}\right)$, but not significantly different with $30 \mathrm{t} \mathrm{ha}^{-1}\left(\mathrm{KD}_{3}\right)$ and $10 \mathrm{t} \mathrm{ha}^{-1}$ $\left(\mathrm{KD}_{1}\right)$ respectively $316.16 \mathrm{~g}$ and $321.70 \mathrm{~g}$. Phonska dose treatment $300 \mathrm{~kg} \mathrm{ha}^{-1}\left(\mathrm{PD}_{2}\right)$ gave the highest dry weight of plant stem with $363,44 \mathrm{~g}$, which was significantly different with treatment without phonska $\left(\mathrm{D}_{0}\right)$ of $251,10 \mathrm{~g}$, but not significantly different with $300 \mathrm{~kg} \mathrm{ha}^{-1}\left(\mathrm{PD}_{3}\right)$ and $150 \mathrm{~kg} \mathrm{ha}^{-1}\left(\mathrm{PD}_{1}\right)$ respectively $320.74 \mathrm{~g}$ and $314.20 \mathrm{~g}$ (Table 3). Based on the above description it can be seen that the dosing interval 10-15 $\mathrm{t} \mathrm{ha}^{-1}$ biochar, 10-30 $\mathrm{t} \mathrm{ha}^{-1}$ compost fertilizer, and 150-450 kg ha-1 phonska fertilizer gives the highest value of the dry weight of plant stalk, while without fertilizer treatment Give the lowest value.

\subsection{Total Dry Weight of Plant}

The highest total dry weight of the plant was obtained at the dose of biochar $10 \mathrm{tha}^{-1}\left(\mathrm{BD}_{2}\right)$ of 509.31 $\mathrm{g}$ which was significantly different with $15 \mathrm{t} \mathrm{ha}^{-1}\left(\mathrm{BD}_{3}\right), 5 \mathrm{t} \mathrm{ha}^{-1}\left(\mathrm{BD}_{1}\right)$, and without biochar $\left(\mathrm{D}_{0}\right)$ Respectively $475.48 \mathrm{~g}, 458.08 \mathrm{~g}$, and $410.90 \mathrm{~g}$. Treatment of compost dose of $20 \mathrm{tha} \mathrm{ha}^{-1}\left(\mathrm{KD}_{2}\right)$ gave the highest total dry weight of $525,05 \mathrm{~g}$ with no treatment $\left(\mathrm{D}_{0}\right)$, but not significantly different with compost dose of $30 \mathrm{t} \mathrm{ha}^{-1}\left(\mathrm{KD}_{3}\right)$ and compost $10 \mathrm{t} \mathrm{ha}^{-1}\left(\mathrm{KD}_{1}\right)$ respectively $498.96 \mathrm{~g}$ and $496.90 \mathrm{~g}$. Treatment of phonska dose of $300 \mathrm{~kg} \mathrm{ha}^{-1}\left(\mathrm{PD}_{2}\right)$ gave the highest total dry weight of 563,91 $\mathrm{g}$, which was not significant with phonska treatment of $450 \mathrm{~kg} \mathrm{ha}^{-1}\left(\mathrm{PD}_{3}\right)$ of $519,34 \mathrm{~g}$, but was significantly different from 
without treatment $\left(\mathrm{D}_{0}\right)$ and dose of phonska $150 \mathrm{~kg} \mathrm{ha}^{-1}\left(\mathrm{PD}_{1}\right)$ respectively $410.90 \mathrm{~g}$ and $498.93 \mathrm{~g}$ (Table 3). Based on the results of this study showed that doses of $10 \mathrm{t} \mathrm{ha}^{-1}$ biochar, 10-30 $\mathrm{t} \mathrm{ha}^{-1}$ compost dose and $300-450 \mathrm{~kg} \mathrm{ha}^{-1}$ phonska obtained the best value of the total dry weight of the plant, whereas without fertilizer treatment gave the lowest value of the weight dry plant total.

Table 3

Average The Fresh Weight of The Cob Without Husk, The Weight of Fresh Seeds, Dry Weight of Seeds Moisture Content 14\%, Dry Weight of Stover, and Total Oven Dry Weight of Plants Because of The Influence of The Type and Dose of Fertilizer

\begin{tabular}{|c|c|c|c|c|c|}
\hline Treatment & $\begin{array}{l}\text { The fresh } \\
\text { the weight of cob } \\
\text { without husk }\end{array}$ & $\begin{array}{l}\text { The weight } \\
\text { of fresh seeds }\end{array}$ & $\begin{array}{c}\text { Dry weight of } \\
\text { seeds moisture } \\
\text { content } 14 \% \\
\end{array}$ & $\begin{array}{c}\text { Dry weight } \\
\text { of stover }\end{array}$ & $\begin{array}{l}\text { Total dry } \\
\text { weight } \\
\text { of plant } \\
\end{array}$ \\
\hline Type Fertilizer & \multicolumn{5}{|c|}{-------------------------- $\left(\mathrm{g} \mathrm{tan}^{-1}\right)$------------------------ } \\
\hline Biochar (B) & $217.19 \mathrm{a}$ & $161.03 \mathrm{a}$ & $142.03 \mathrm{a}$ & 293.96 a & $463.44 \mathrm{a}$ \\
\hline Compost $(\mathrm{K})$ & $215.55 \mathrm{a}$ & $162.26 \mathrm{a}$ & $144.59 \mathrm{a}$ & $307.87 \mathrm{a}$ & $482.96 \mathrm{a}$ \\
\hline Phonska (P) & $240.97 \mathrm{a}$ & $175.34 \mathrm{a}$ & $157.42 \mathrm{a}$ & $312.37 \mathrm{a}$ & $498.27 \mathrm{a}$ \\
\hline BNT 5\% & - & - & - & - & - \\
\hline \multicolumn{6}{|l|}{ Dose of Biochar } \\
\hline $0 \mathrm{t} \mathrm{ha}^{-1}\left(\mathrm{D}_{0}\right)$ & $179.63 \mathrm{~b}$ & $142.03 \mathrm{a}$ & $130.85 \mathrm{a}$ & $251.10 \mathrm{c}$ & $410.90 \mathrm{c}$ \\
\hline $5 \mathrm{t} \mathrm{ha}^{-1}\left(\mathrm{BD}_{1}\right)$ & $226.33 \mathrm{a}$ & $165.67 \mathrm{a}$ & $135.12 \mathrm{a}$ & $276.48 \mathrm{bc}$ & $458.08 \mathrm{~b}$ \\
\hline $10 \mathrm{t} \mathrm{ha}^{-1}\left(\mathrm{BD}_{2}\right)$ & $240.00 \mathrm{a}$ & $170.83 \mathrm{a}$ & $158.99 \mathrm{a}$ & $343.58 \mathrm{a}$ & $509.31 \mathrm{a}$ \\
\hline $15 \mathrm{t} \mathrm{ha}^{-1}\left(\mathrm{BD}_{3}\right)$ & $222.80 \mathrm{a}$ & $165.60 \mathrm{a}$ & $143.18 \mathrm{a}$ & $304.68 \mathrm{ab}$ & $475.48 \mathrm{ab}$ \\
\hline \multicolumn{6}{|l|}{ Dose of Compost } \\
\hline $0 \mathrm{t} \mathrm{ha}^{-1}\left(\mathrm{D}_{0}\right)$ & $179.63 \mathrm{~b}$ & $142.03 \mathrm{a}$ & $130.85 \mathrm{a}$ & $251.10 \mathrm{~b}$ & $410.90 \mathrm{~b}$ \\
\hline $10 \mathrm{t} \mathrm{ha}^{-1}\left(\mathrm{KD}_{1}\right)$ & $220.03 \mathrm{a}$ & $160.63 \mathrm{a}$ & $143.49 \mathrm{a}$ & $321.70 \mathrm{a}$ & $496.90 \mathrm{a}$ \\
\hline $20 \mathrm{t} \mathrm{ha}^{-1}\left(\mathrm{KD}_{2}\right)$ & $230.10 \mathrm{a}$ & $169.37 \mathrm{a}$ & $149.07 \mathrm{a}$ & $342.52 \mathrm{a}$ & $525.05 \mathrm{a}$ \\
\hline $30 \mathrm{t} \mathrm{ha}^{-1}\left(\mathrm{KD}_{3}\right)$ & $232.43 \mathrm{a}$ & $177.00 \mathrm{a}$ & $154.96 \mathrm{a}$ & $316.16 \mathrm{a}$ & $498.96 \mathrm{a}$ \\
\hline \multicolumn{6}{|l|}{ Dose Phonska } \\
\hline $0 \mathrm{~kg} \mathrm{ha}^{-1}\left(\mathrm{D}_{0}\right)$ & $179.63 \mathrm{c}$ & $142.03 \mathrm{~b}$ & $130.85 \mathrm{~b}$ & $251.10 \mathrm{~b}$ & $410.90 \mathrm{c}$ \\
\hline $150 \mathrm{~kg} \mathrm{ha}^{-1}\left(\mathrm{PD}_{1}\right)$ & $233.10 \mathrm{~b}$ & $171.70 \mathrm{ab}$ & $154.57 \mathrm{ab}$ & $314.20 \mathrm{a}$ & $498.93 \mathrm{~b}$ \\
\hline $300 \mathrm{~kg} \mathrm{ha}^{-1}\left(\mathrm{PD}_{2}\right)$ & $284.80 \mathrm{a}$ & $189.10 \mathrm{a}$ & $168.53 \mathrm{a}$ & $363.44 \mathrm{a}$ & $563.91 \mathrm{a}$ \\
\hline $450 \mathrm{~kg} \mathrm{ha}^{-1}\left(\mathrm{PD}_{3}\right)$ & $266.33 \mathrm{ab}$ & $198.53 \mathrm{a}$ & $175.74 \mathrm{a}$ & $320.74 \mathrm{a}$ & $519.34 \mathrm{ab}$ \\
\hline LSD $5 \%$ & 37.20 & 32.21 & 25.04 & 50.42 & 43.21 \\
\hline $\mathrm{CD}$ & $9.78 \%$ & $11.45 \%$ & $9.99 \%$ & $9.77 \%$ & $5.30 \%$ \\
\hline
\end{tabular}

Description: The numbers followed by the same letters in the same column are not significantly different at $5 \%$ LSD. CD = Coefficient of Diversity

\subsection{Effect of Biochar on Total Plant Dry Weights}

The results showed that dosage of biochar $10 \mathrm{t} \mathrm{ha}^{-1}$ gave the best result of the total dry weight of plant (Table 3). The highest total dry weight of the plant obtained at a dose of biochar $10 \mathrm{t} \mathrm{ha}^{-1}$ of $509.31 \mathrm{~g}$ increased by $23.95 \%$ when compared with no biochar of $410.90 \mathrm{~g}$.

The result of regression analysis between a dose of biochar with total dry weight showed a quadratic relationship with regression line equation: $\hat{Y}=406,4+17,05 X-0,81 \mathrm{X}^{2}$, with a coefficient of determination $\left(\mathrm{R}^{2}\right)$ equal to $74,00 \%$. Based on a result of regression analysis got an optimum dose of biochar 10,52 $\mathrm{t} \mathrm{ha}^{-1}$ and total dry weight of plant 496,12 $\mathrm{g}$ (Fig. 2). The high total dry weight of the plants at the optimum dosage treatment of biochar $10.52 \mathrm{t} \mathrm{ha}^{-1}$ was thought to be caused by biochar as a soil enhancer able to improve soil properties. The effect of biochar on soil properties can increase soil porosity, water holding capacity, CEC, BS, C-organic, nutrients, and microbial activity in the soil. Biochar can serve as a soil enhancer, enhancing plant growth by supplying a number of useful nutrients as well as improving the physical and biological properties of the soil [17], [18]. Biochar may increase the $\mathrm{pH}, \mathrm{BS}$, and CEC of the soil [14]. According to [15], the higher content of N, P, K on biochar-treated soils suggests a positive contribution of organic enhancers to improved soil nutrient availability. These soil properties are very important in encouraging early growth and stimulating the vegetative growth of plants. Increased vegetative growth of plants can increase the rate of growth and development of plants because the amount of light that can be intercepted in the process of photosynthesis to form dry matter plants. The assimilates formed as a result of the photosynthesis process will be used for the formation of 
new cells in the process of growth and development of plant vegetative organs as well as the translocation of photosynthate which is fed to corn cobs for seed filling.

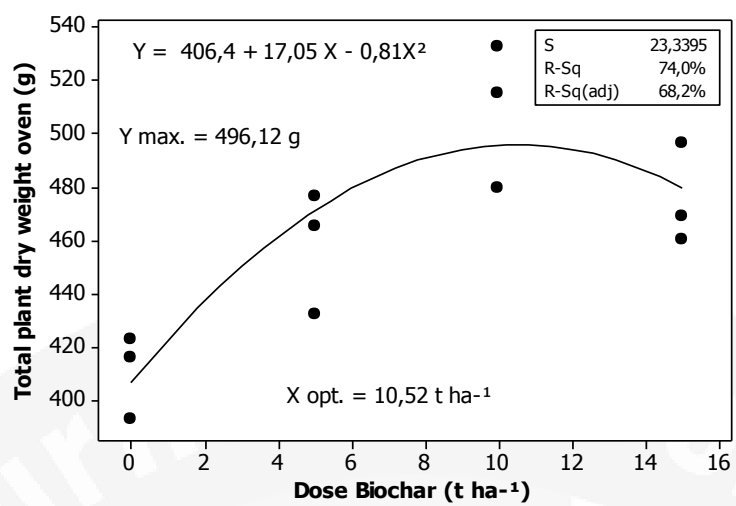

Figure 2. The Relationship Between The Dose of Biochar by Total Dry Weight of Plants

\subsection{Effect of Compost on Total Dry Weight of The Plant}

The results showed that compost doses of 10-30 $\mathrm{t} \mathrm{ha}^{-1}$ gave the best results of total dry weight of plants (Table 3). The highest total dry weight of the plant was obtained at compost dose of $20 \mathrm{t} \mathrm{ha}^{-1}$ of $525.05 \mathrm{~g}$, an increase of $27.78 \%$ when compared with no treatment of $410.90 \mathrm{~g}$.

The result of regression analysis between the dose of compost fertilizer and total dry weight showed quadratic correlation with regression line equation: $\hat{Y}=411,1+11,33 \mathrm{X}-0,2802 \mathrm{X}^{2}$, with the coefficient of determination $\left(\mathrm{R}^{2}\right)$ equal to $82,40 \%$. Based on a result of regression analysis obtained an optimum dosage of compost is $20,22 \mathrm{t} \mathrm{ha}^{-1}$ with the total dry weight of plant 525,63 $\mathrm{g}$ (Fig. 3). The high dry weight of the total plant at the optimum dosage of $20.22 \mathrm{t} \mathrm{ha}^{-1}$ was thought to be caused by compost fertilizer able to improve soil properties and soil quality. Compost fertilizer is the result of decomposition of organic materials that can improve the physical, chemical, and biological properties of the soil, such as increasing the capacity of groundwater retention, soil porosity, $\mathrm{pH}, \mathrm{CEC}$, and soil CEC, as well as nutrients N, P, K and C-organic soil. According to [8], that compost contains humic acid which can increase cation exchange capacity, increase soil microorganism activity, increase soil $\mathrm{pH}$, provide macro and micro nutrients. According to [19], compost can improve soil structure, increase groundwater capacity, improve drainage and air-conditioning in the soil, enhance soil-binding capacity to nutrients, complete nutrients, and as food for microbes.

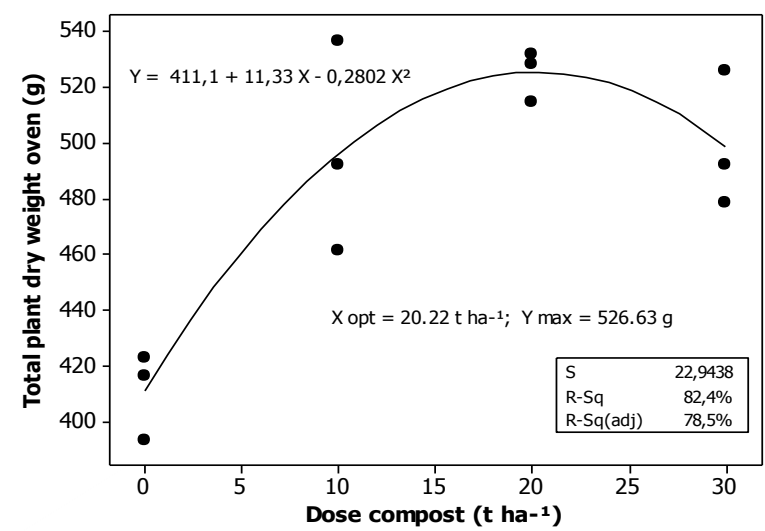

Figure 3. The Relationship Between The Dose of Compost in Total Dry Weight of Plants

\subsection{Effect of Phonska on Total Dry Weight of Plants}

The results showed that the phonska dose of $300-450 \mathrm{~kg} \mathrm{ha}^{-1}$ gave the best result of the total dry weight of the plant (Table 3). The highest total dry weight of plants was obtained at phonska dose of 300 $\mathrm{kg} \mathrm{ha}^{-1}$ of $563.91 \mathrm{~g}$, an increase of $37.24 \%$ when compared with no treatment of $410.90 \mathrm{~g}$. Regression test between dose of phonska with total dry weight showed quadratic relationship with equation of regression 
line: $\hat{\mathrm{Y}}=406,6+0,9232 \mathrm{X}-0,001473 \mathrm{X}^{2}$, with coefficient of determination $\left(\mathrm{R}^{2}\right)$ equal to $82,20 \%$, optimum dose of phonska $313,37 \mathrm{~kg} \mathrm{ha}^{-1}$ and total dry weight of plant maximum 551,25 g (Fig. 4).

The high dry weight of the total plant at the optimum dosage of phonska fertilizer $313,37 \mathrm{~kg} \mathrm{ha}^{-1}$ was caused by phonska fertilizer able to provide nutrient NPK for the growth of corn crop. NPK phonska fertilizer is also known as compound fertilizer because it contains the main nutrient content of more than two types, with nutrient content of $\mathrm{N}(15 \%)$ in the form of $\mathrm{NH}_{3}, \mathrm{P}(15 \%)$ in the form of $\mathrm{P}_{2} \mathrm{O}_{5}$ and $\mathrm{K}(15 \%)$ in the form $\left(\mathrm{K}_{2} \mathrm{O}\right)$. The phosphorus element plays an important role in the transfer of energy within the plant cell, promotes early root development and fertilization, strengthens the stem so that it does not easily fall down, and increases the $\mathrm{N}$ uptake at the beginning of growth. Potassium element in plant growth to stimulate the translocation of carbohydrates from leaf to plant organ [20]. According to [21], the function: (1) nitrogen serves to stimulate the growth of plants, especially stems, branches, leaves, and plays an important role in the formation of green leaf in the process of photosynthesis and the formation of proteins, fats, and various other organic compounds, Functioning to stimulate root growth, as a raw material of protein formation, assisting assimilation of breathing and accelerate flowering, seed and fruit maturation, (3) potassium function in strengthening plant body so that leaves, flowers, and fruits do not easily fall, increase crop resistance to drought and Disease, and play a role in helping the formation of proteins and carbohydrates.

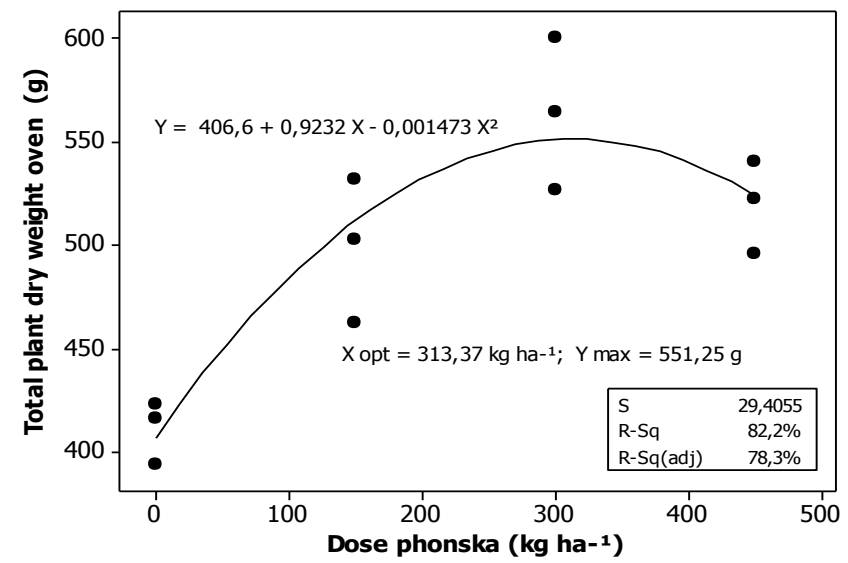

Figure 4. The Relationship Between Dose Phonska by Total Dry Weight of Plant

\section{Conclusion}

1. The dose of biochar $10 \mathrm{t} \mathrm{ha}^{-1}$ gave the highest total dry weight of the plant of $509.31 \mathrm{~g}$, which increased by $23.95 \%$ when compared with without biochar of $410.90 \mathrm{~g}$.

2. Compost doses of $20 \mathrm{t} \mathrm{ha}^{-1}$ gave the highest total dry weight of the plant of $525.05 \mathrm{~g}$, an increase of $27.78 \%$ when compared with no treatment of $410.90 \mathrm{~g}$.

3. Phonska doses of $300 \mathrm{~kg} \mathrm{ha}^{-1}$ gave the highest total dry weight of the plant of $563.91 \mathrm{~g}$, an increase of $37.24 \%$ when compared with no treatment of $410.90 \mathrm{~g}$.

4. The best dosage of biochar $10 \mathrm{t} \mathrm{ha}^{-1}$, compost $10-30 \mathrm{t} \mathrm{ha}^{-1}$, and phonska $300-450 \mathrm{~kg} \mathrm{ha}^{-1}$ can be used to increase the yield of maize on dry land.

5. The optimum dose of bamboo biochar $10.52 \mathrm{t} \mathrm{ha}^{-1}$, compost $20,22 \mathrm{t} \mathrm{ha}^{-1}$, and phonska $313,37 \mathrm{~kg} \mathrm{ha}^{-1}$ can give a maximum yield of the corn plant in the dry land.

\section{Acknowledgments}

The authors would like to thank the promoter and co-promoter who attentively, provide guidance and advice to the author. The authors also thank our friends and everyone for the help and support given to the author. 
References

[1] Hidayat, A., Hikmatullah, and Santoso, D. 2000. Potential and management of lowland dry land. Indonesia's Land Resources and Its Management. Soil and Agro-climate Research Center, Bogor: p. 197-222.

[2] International Biochar Initiative, 2012. What is Biochar ?. International Biochar Initiative (IBI). Www.biochar-international.org.

[3] Nurida, N. L., and Rachman, A. 2011. Alternative Recovery of Dried Oily Land Degraded with Biochar Soil Formulation Formula at Typic Kanhapludults Lampung. Agricultural Research Agency, Indonesian Soil Research Institute: 639-648.

[4] Bambang, S.A., 2012. The Black Biochar Multipurpose. PT. Perkebunan Nusantara X (Persero), Surabaya.

[5] Rostaliana, P. Prawito, P., and Turmudi, E., 2012. Utilization of Biochar for soil quality improvement with indicators of hybrid corn and upland rice in slash and burn land systems. Naturalist-Journal of Natural Resource and Environmental Research. Univ. Bengkulu. Vol 1 No. 3: $179-188$

[6] Isroi, 2008. Compost. Indonesian Plantation Biotechnology Research Institute, Bogor. Www.isroi.org

[7] Petrokimia Gresik, 2016. Phonska Fertilizer. Http: // www. Petrokimia-gresik / fertuk / phonska.NPK.

[8] Novizan, 2007. Effective Fertilization Guidelines. Jakarta: Agromedia Pustaka.

[9] Situmeang, Y.P. And Sudewa, K.A. 2013. Vegetative Growth Response of Maize in Biochar Application of Bamboo Waste. Proceedings of the National Seminar. Faculty of Agriculture Universitas Warmadewa. Denpasar.

[10] Sujana, I P., Lanya, I., Subadiyasa, I.N.N \& Suarna, I.W. 2014. The effect of dose biochar and organic matters on soil characteristic and corn plants growth on the land degraded by garment liquid waste. Journal of Biology, Agriculture and Healthcare, 4 (5). 77-88.

[11] Situmeang, Y. P., Adnyana, I. M., Subadiyasa, I. N. N., \& Merit, I. N. (2015). Effect of Dose Biochar Bamboo, Compost, and Phonska on Growth of Maize (Zea mays L.) in Dryland. International Journal on Advanced Science, Engineering and Information Technology, 5 (6), 433439.

[12] Situmeang, Y.P., Sudewa, K.A. Suarta, M., and Risa, A.A.S. 2016. Biochar and Compost on the Growth and Yield of Sweet Corn. Agricultural Gema Agro Journal. Faculty of Agriculture Universitas Warmadewa. Denpasar.

[13] Situmeang, Y.P, Udayana, I.G.B., Mayun Wirajaya, A.A.N., Suarta, M., Suaria I.N, Sadguna, D.N., Yuliartini, M.S., and Wahyuni, N.M.D. 2013. Potential of Bamboo Waste as a Source of Community-Based Biomass Raw Materials Supply. Proceedings of the National Seminar. Faculty of Agriculture Universitas Warmadewa. Denpasar.

[14] Liang, B, Lehmann, J, Solomon, D, Kinyangi, J, Grossman, J, O'Neill, B, Skjemstad, JO, Thies, JE, Luizao, FJ, Petersen, J \& Neves, EG 2006. Black carbon increases cation exchange capacity in soils, Soil Science Society of America Journal 70: 1719-1730.

[15] Lehmann, J. 2007. A handful of carbon. Nature, 447: 143-144.

[16] Hua, L., Wu, W., Liu, Y., McBride, M. B. And Chen, Y. 2009. Reduction of nitrogen loss and Cu and $\mathrm{Zn}$ mobility during sludge composting with a bamboo charcoal amendment. Environmental Science and Pollution Research 16: 1-9.

[17] Lehmann, J. and Rondon, M. 2005, 'Bio-char soil management on highly weathered soils in the humid tropics', in N. Uphoff (ed.), Biological Approaches to Sustainable Soil Systems, Boca Raton, CRC Press, in press.

[18] Steiner, Christoph, Teixeira, Wenceslau, Lehmann, Johannes, Nehls, Thomas, de Macdo, Jefferson, Blum, Winfried, and Zech, Wolfgang. 2007. Long term effects of manure, charcoal and mineral fertilization on crop production and fertility on a highly weathered Central Amazonian upland soil. Plant and Soil 291: 275-290. Springer Netherlands.

[19] Indriani, Y.H. 2008. Make Compost Quickly. The Swadaya spreader. Jakarta.

[20] Agustina, L. 2004. Basic Nutrition Plant. PT. Rineka Cipta. Jakarta.

[21] Linga, P. and Marsono. 2007. Fertilizer Use Instructions. Spread Self-Spreader, Jakarta. 


\section{Biography of Author}

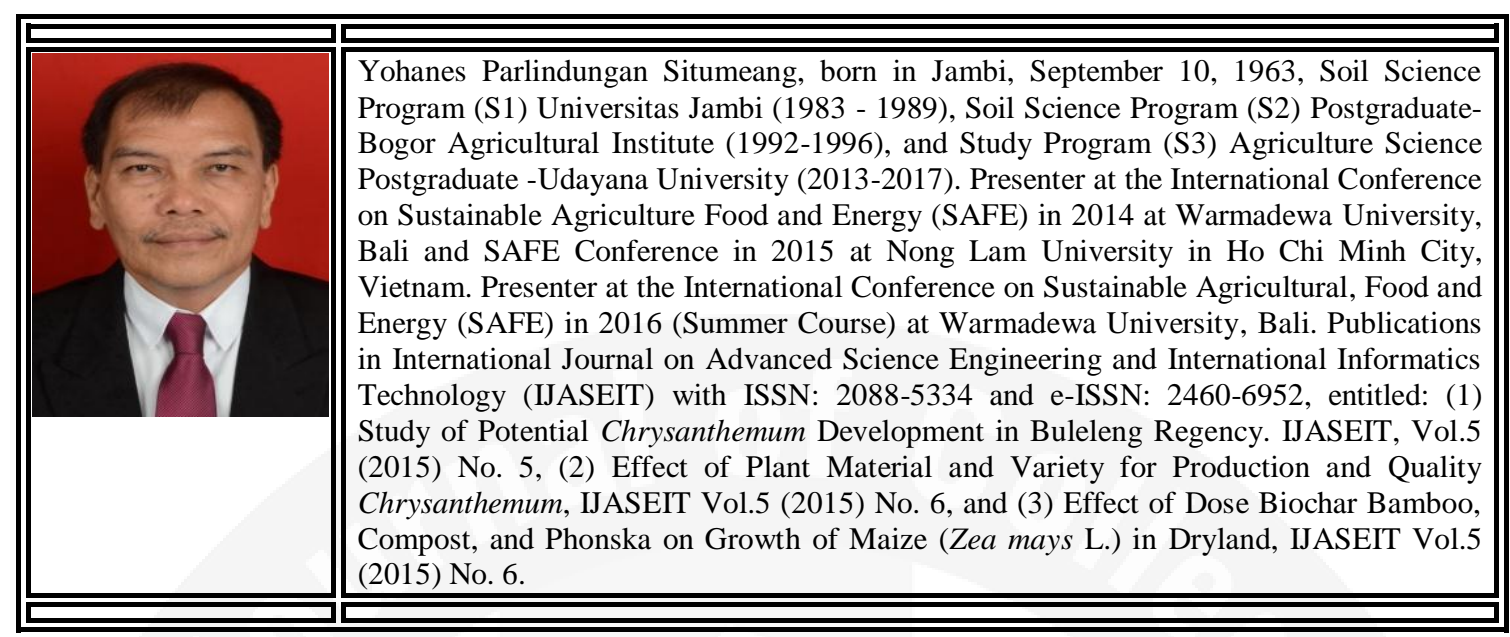

